\title{
Calculators in Divinity: Henry Savile and Thomas Bradwardine
}

\author{
Scott Mandelbrote \\ Fellow and Perne Librarian, Peterhouse, Cambridge, UK \\ shm24@cam.ac.uk
}

\begin{abstract}
This essay discusses the immediate context and form of the publication of Henry Savile's edition of Thomas Bradwardine's De causa Dei (1618). It sets out the political and theological significance of the work in relation to publications of the King's Printers, the Synod of Dort, and the activities of Archbishop Abbot. It moves on to consider how the edition was made, resituating it in Oxford intellectual life of the early 1610 s and in the broader world of theological controversy, and identifying some of those who conceived and assisted with the work. It considers which manuscripts were used in making the edition.
\end{abstract}

\section{Keywords}

Savile - Abbot - Bradwardine - predestination - free will - Oxford - Synod of Dort - printing

But what $\mathrm{y}^{\mathrm{t}}$ God afore wote, must nedes bee After the opinion of certaine clerkes Witnesse of him, that any clerke is That in schole is great alteracion In this mater, and great disputacion And hath ben, of an hundred thousand men But I ne can nat boulte it to the bren As can the holy doctour saint Austin Or Boece, or the bishop Bradwardin Whether that goddess worthy foreweting Straineth me nedely to do a thing 
(Nedely clepe I simple necessitie)
Or if the free choice be graunted me
To do the same thing, or do it nought
Though God forewote it, er it was wrought ${ }^{1}$

In the Nun's Priest's Tale, Chaucer introduced the figure of Thomas Bradwardine (c. 1300-1349) alongside that of St Augustine as someone who had understood the otherwise incomprehensible problem posed by divine foreknowledge for human free will. Bradwardine, whom Henry Savile believed to have been born in 1290, had been consecrated as archbishop of Canterbury in $1348 .^{2}$ His earlier clerical career had included service from 1337 as chancellor of St Paul's Cathedral. At first apparently a client of Richard de Bury, the powerful and bibliophile bishop of Durham, Bradwardine later entered the service of Edward II I and witnessed the king's success in the war in France. He remained in touch, however, with the scholarly environment of Merton College, Oxford, of which he had become a fellow in $1323 .{ }^{3}$ There he was involved in debates between the followers of Duns Scotus and those of Thomas Aquinas, and in the furore over William of Ockham's annotations on the Sentences of Peter Lombard, which were condemned at both Oxford and Avignon in 1326. Whereas Bradwardine would eventually stress the necessity of divine will in the transforming power of grace, Ockham drew out its contingency. In particular, he suggested that the gift of grace implied divine acceptance of an act whose merit arose from the free will of its human actor. ${ }^{4}$ This theological debate was the initial context for the lectures that Bradwardine reworked in 1344 as De causa Dei, and that he addressed from London to his fellow Mertonians in order to combat the rise of what he considered to be neo-Pelagianism.

Although De causa Dei circulated reasonably widely in the later Middle Ages (more than fifty manuscripts reproducing at least part of it survive), it was not

$1 \quad$ Geoffrey Chaucer, Workes (London, 1598), fol. 87r; cf. Thomas Bradwardine, De cavsa Dei, contra Pelagivm et de virtvte cavsarvm ad suos Mertonenses, libri tres, ed. Henry Savile (London, 1618), sig. a3v.

2 Bradwardine, De cavsa Dei, ed. Savile, sig. a2v; for a modern outline of Bradwardine's life, see the entry by Gordon Leff in $O D N B$.

3 G. H. Martin and J. R. L. Highfield, A History of Merton College (Oxford, 1997), 56-59.

4 For discussion of these topics, see Gordon Leff, Bradwardine and the Pelagians (Cambridge, 1957); H. A. Oberman, Archbishop Thomas Bradwardine. A Fourteenth Century Augustinian (Utrecht, 1958); James A. Weisheipl, 'Ockham and some Mertonians', Mediaeval Studies 30 (1968), 163-213. I have not been able to consult Brian Fleming's 1964 Louvain dissertation, Thomas de Bradwardine. 
one of his writings that found its way into print in the late fifteenth or early sixteenth centuries. ${ }^{5}$ Instead it was first edited by another Mertonian, Henry Savile (1549-1622), at the time both warden of the college and provost of Eton College. The peculiarities of Savile's edition deserve more attention than they have hitherto received, even though the immediate context for its reception in the Arminian controversy that was eventually played out at the Synod of Dort $(1618-19)$ has been obvious to a number of scholars. ${ }^{6}$

Savile's edition of Bradwardine's De causa Dei was entered in the Stationers' Register on 21 July 1617 to John Bill (1576-1630), one of the partners in the office of the King's Printer. ${ }^{7}$ Savile was still at work on the historical details of the preface, in which he sketched out Bradwardine's career and determined that he had died in 1349, in February and March 1618. At the same time, he was also contemplating how to word the dedication to James VI \& I, using the antiquary and herald William Camden (1551-1623), whose advice he had taken on sources for Bradwardine's life, as an intermediary with the printer. ${ }^{8}$

Bill and his partner Bonham Norton had just bought out Robert Barker and his son, Christopher, from their interest in the King's Printing House, in a settlement of debt that would soon be taken up in Chancery and referred by the

See James A. Weisheipl, 'Repertorium Mertonense', Mediaeval Studies 31 (1969), 174-224, at 181; Richard Sharpe, A Handlist of the Latin Writers of Great Britain and Ireland before 1540 (Turnhout, 1997), 642-644; Edit Anna Lukács, 'Die Handschriften von Thomas Bradwardines Traktat De causa Dei in Österreich', Codices Manuscripti et Impressi 99/100 (2015), 3-10. See also Thomas Bradwardine, De causa Dei contra Pelagium et de virtute causarum, ed. Edit Anna Lukács (Göttingen, 2013), 11-13. Both Weisheipl and Sharpe give the impression that earlier editions than Savile's exist, but these are confusions with the publication of Bradwardine's writings on geometry, arithmetic, and the art of memory.

6 Nicholas Tyacke, Anti-Calvinists. The Rise of English Arminianism c. 1590-1640 (Oxford, 1987), 56; Luca Baschera, 'Witnessing to the Calvinism of the English Church: The 1618 Edition of Thomas Bradwardine's “De Causa Dei Adversus Pelagium”, in Bewegung und Beharrung, Aspekte des reformierten Protestantismus, 1520-1650, eds Christian Moser and Peter Opitz (Leiden, 2009), 433-446.

7 Edward Arber, ed., A Transcript of the Registers of the Company of Stationers of London, 1554-1660, 5 vols (London, 1875), 3: 612.

8 Thomas Smith, ed., V. Cl. Gulielmi Camdeni, et illustrium virorum ad G. Camdenum epistolae (London, 1691), 219-220, 224-225. The dedication leaf (which is found between the titlepage and sig. a2) is signed 'a' but is in fact a cancel, inserted after the rest of the first quire of the book had been printed. Although present, it was not bound into Savile's own copy of the book, see S. Leigh Sotheby and John Wilkinson, Catalogue of a Selection of Singularly Curious \& Rare Books from the Libraries of those Eminent Scholars, Sir Henry Savile and Sir John Savile (London, 1860), 24, number 228. Royal involvement and approval were not, however, an afterthought for Savile's edition, as other evidence shows. Another inserted leaf follows p. 876 in some but by no means all copies and bears two columns of errata: see, for example, Oxford, Merton College, shelfmark 46. a. 12. 
court to Savile for arbitration. ${ }^{9}$ As Maria Wakely and the late Graham Rees have shown, the edition of Bradwardine formed part of a group of nine impressive, folio works written or edited by leading figures in the government of James VI \& I, which were produced by the King's Printers between 1616 and 1620, and which testified to royal faith in the power of the printed word to determine political and religious debate. ${ }^{10}$ The books concerned (other than De causa Dei) were the works (in English and later in Latin) of James VI \& I, edited by James Montagu, then bishop of Bath and Wells and later bishop of Winchester; two volumes of the anti-papal De Republica Ecclesiastica of the renegade archbishop of Split, Marc' Antonio de Dominis; the similarly critical history of the Council of Trent written by the Venetian, Paolo Sarpi (also a friend of De Dominis), which appeared in Italian, English, and Latin versions; and Francis Bacon's Instauratio magna. Several of these publications, including De causa $D e i$, were later named by Bill as having been loss-making undertakings that he had been required to print 'for $\mathrm{y}^{\mathrm{e}}$ advancement of $\mathrm{o}^{\mathrm{r}}$ religion \& honor of $\mathrm{y}^{\mathrm{e}}$ Nation..11 The demands that the almost simultaneous production of such substantial books made on the King's Printing House were considerable. Certainly, Bonham Norton, Bill's partner and the holder of the patent for the printing of Latin books on behalf of the Crown, judged initially that De causa Dei was too expensive to take on. ${ }^{12}$ The work only went ahead after the king had expressed his displeasure and, through the secretary of state, Sir Ralph Winwood, compelled Norton to acquire the necessary materials for the edition. In a later suit in Chancery between Bill and Norton, Bill asserted his own willingness to comply with such demands even at his own loss. ${ }^{13}$

As publishers of Latin books, Bill and Norton had established contacts at the bi-annual, eight-day Frankfurt book fair, through which learned works were traded across Europe. From 1617, Bill produced a version of the catalogues of the Frankfurt fair, promoting his own books as well as others that he would be able to obtain from Germany. Bradwardine's De causa Dei was quickly advertised in the catalogue that Bill printed following the September

9 See Henry R. Plomer, 'The King's Printing House under the Stuarts', The Library and series 2 (1901), 353-375, especially 356-36o.

10 Maria Wakely and Graham Rees, 'Folios fit for a King: James I, John Bill, and the King's Printers, 1616-1620', Huntington Library Quarterly 68 (2005), 467-495; Graham Rees and Maria Wakely, Publishing, Politics, and Culture. The King's Printers in the Reign of James I and VI (Oxford, 2009), 93-120. W. W. Greg, ed., A Companion to Arber (Oxford, 1967), 257-258; cf. W. A. Jackson, ed., Records of the Court of the Stationers' Company 1602 to 1640 (London, 1957), 101, 362-364.

12 Rees and Wakely, Publishing, Politics, and Culture, 36, 152-153.

13 Kew, The National Archives [henceforth TNA], C5/592/24 (Bill v. Norton). 
fair in $1617 \cdot{ }^{14}$ An invoice kept by Bill for the natural philosopher, Thomas Harriot, from 31 October 1617 to 29 July 1618, which featured heavily books advertised in the fair catalogues, provides a contemporary sale price for $D e$ causa Dei of 15 shillings. ${ }^{15}$ The edition of Bradwardine continued to appear, shifting its location among other publications, in subsequent fair catalogues issued by Bill until his final catalogue in 1628. Copies were certainly sold into the continental market in this way, even during the period of time, between 1622 and 1627, when Bill ceded his interest in the Latin stock to the Stationers' Company. The Antwerp bookseller, Jan II Moretus at the Officina Plantiniana, took two copies at the autumn fair in 1626 . His purchases from Bill and Norton more broadly draw attention to the relationship that Savile had had for some time with the King's Printers. John Norton, then the King's Printer, was effectively the publisher for the Greek patristic editions that Melchisidec Bradwood printed on behalf of Savile at his Eton press in the early 1610 s. Bill and Bonham Norton, as partners in the Latin stock, were later the conduit for the sale to Moretus, for example, of Richard Montagu's edition of the invectives against Julian the Apostate by Gregory of Nazianzus (Eton, 1610), as well as for the enormous and remarkable Eton edition of the works of John Chrysostom (Eton, 1610-1613). ${ }^{16}$

Savile also intervened personally, notably through the network provided by the embassies of his son-in-law, Sir Dudley Carleton (1573-1632), to Venice from 1610 to 1615 and at the Hague from 1616, to promote the distribution of

14 Catalogvs vniversalis pro nvndinis Francofurtensibvs avtvmnalibus, de anno M. D. C. XVII. (London, 1617), sig. Aiv. On Bill's role in the international trade in Latin books, see Rees and Wakely, Publishing, Politics, and Culture, 190-241. For the Frankfurt fair, see Ian Maclean, Scholarship, Commerce, Religion. The Learned Book in the Age of Confessions, 1560-1630 (Cambridge MA, 2012).

15 Chichester, West Sussex Record Office, Petworth House Archive, HMC 241/4, fol. gr-v; printed in Scott Mandelbrote, 'The Religion of Thomas Harriot', in Thomas Harriot. An Elizabethan Man of Science, ed. Robert Fox (Aldershot, 2000), 246-279, at 272-279. The earliest evidence for institutional purchase of which I am aware is that of Peterhouse, Cambridge, which acquired a copy by 24 March 1619: see Ward Library, Peterhouse, MS 405, fol. $33 \mathrm{v}$. It is unlikely that this is the copy which survives in the library, since that derives from the donation in 1635 of some of the books of the Mertonian physician, Theodore Gulston. Gulston's copy (Peterhouse, Perne Library, shelfmark H. 4. 24) lacks the errata and has printer's waste from the edition used in its gilt-tooled binding, suggesting in turn that it was acquired close to the time of publication.

Rees and Wakely, Publishing, Politics, and Culture, 204-207, 213-214, 222, 230-231. For Bradwood, see R. B. McKerrow, ed., A Dictionary of Printers and Booksellers, 1557-1640 (London, 1910), 47-48. 
copies of his edition of Chrysostom in Italy and the northern Netherlands. ${ }^{17}$ It is worth dwelling for a while on the nature of Savile's web of contacts and its links with the folio publications of John Bill. Dudley Carleton, who by 1617 hoped to succeed Savile as provost, had been involved with the printing of Greek texts at the Eton press. While in Venice, he encouraged Sarpi in the writing of the history of the Council of Trent, which may in part have been meant as a response to the Consensvs Ecclesice catholicce contra Tridentinos (1613) of his cousin, George Carleton, later bishop of Llandaff. ${ }^{18}$

Carleton also approached Sarpi to write against the ideas of Conrad Vorstius (1569-1622), the successor to the chair of Jacobus Arminius at the University of Leiden, and a theologian whom James VI \& I suspected of denying the orthodox doctrine of the Trinity. ${ }^{19}$ Concerns over the spread of Socinianism meanwhile motivated De Dominis too. He wrote the dedication for John Bill's Italian edition of Sarpi's history, with whose publication he was closely involved, and he also translated Bacon's De sapientia veterum for Bill to print. In 1617, De Dominis was canvassed as dean of the Chapel Royal at Windsor, and when visiting the king there in October crossed the Thames to Eton in the company of the archbishop of Canterbury, where he was welcomed by Savile and his wife. ${ }^{20}$ The interests of Savile and De Dominis were also intertwined in efforts to obtain for Carleton the fruits of the living of Langley, a few miles from Eton, in 1619 and $1620 . .^{21}$

The activity of De Dominis for reunion with the Greek Church chimed strongly with the hopes of George Abbot (1562-1633), archbishop of Canterbury, who was in turn named on the title-page of Savile's edition of Bradwardine as having ordered its publication. Ecclesiastical reunion was one of the matters

17 Kew, TNA, SP 14/72 fols 112r, 212r; SP 14/80, fol. 69r; S. van der Woude, 'Sir Henry Savile's Chrysostomus Edition in the Netherlands', in Stvdia bibliographica in honorem Herman de la Fontaine Verwey, ed. S. van der Woude (Amsterdam, 1966), 437-447; Willem Nijenhuis, ed., Matthew Slade 1569-1628. Letters to the English Ambassador (Leiden, 1986), 16-20.

Maurice Lee, Jr., ed., Dudley Carleton to John Chamberlain 1603-1624 Jacobean Letters (New Brunswick, 1972), 107-108; Gaetano Cozzi, 'Fra Paolo Sarpi, l'anglicanesimo e la Historia del Concilio Tridentino', Rivista storica italiana 68 (1956), 559-619; Kew, TNA, SP 14/92, fol. gor; SP 14/93, fol. 95r.

19 Lee, ed., Dudley Carleton to John Chamberlain, 121-4; David Wootton, Paolo Sarpi between Renaissance and Enlightenment (Cambridge, 1983), 90-93; Frederick Shriver, 'Orthodoxy and Diplomacy: James I and the Vorstius Affair', English Historical Review 85 (1970), 449-474. See Noel Malcolm, De Dominis (1560-1624): Venetian, Anglican, Ecumenist and Relapsed Heretic (London, 1984); W. B. Patterson, James VI and I and the Reunion of Christendom (Cambridge, 1997), 220-259; Kew, TNA, SP 14/93, fols 2r, 227r; for an earlier meeting of Savile and De Dominis, this time at Lambeth, see SP 14/9o, fol. 153r-v. 
under discussion during Dudley Carleton's embassy at the Hague, which overlapped with the meeting of the Synod of Dort. Carleton secured the appointment as a delegate of James VI \& I to the Synod of his cousin, the newly appointed bishop of Llandaff. Savile's sub-warden at Merton and his subsequent successor there as warden, Nathaniel Brent (1573/4-1652), was also a client of Abbot, whose niece he eventually married. Brent travelled to Italy on Carleton's embassy in the service of Savile's stepdaughter, and later acted as Carleton's secretary at the Hague. He was responsible in 1618 for sending the Italian manuscript of Sarpi's history of the Council of Trent clandestinely to England for Bill to publish. At Abbot's instigation, Brent prepared the English translation of Sarpi's text, published in 1620, and wrote the letters of dedication to the king and the archbishop. ${ }^{22}$

The eighteenth-century edition of correspondence found in the papers of the Brent family contains hints of closer involvement by Savile in this broader story of publication. It concludes with a letter from Thomas James 'Philo-Brentius' to the warden of Merton, asking him to arrange the presentation of Sarpi's history of the Council of Trent to Archbishop Abbot. The letter is dated simply 'Augusti septimo [7 August]' and mentions the expectation of a meeting of Parliament. It is likely that the author of the letter was Thomas James (1572/3-1629), who served as Bodley's librarian until his resignation in 1620. It is possible that the letter is to Nathaniel Brent, in which case it would have to have been written after 1622 and to relate to the second edition in English of Sarpi's history, published in 1629. Parliament had been prorogued in June 1628 and met again in January 1629. But there are various reasons for thinking that the letter might in fact be addressed to Savile and have been written in 1619 or possibly 1620 . One of these is that it makes no mention of the additions made to the 1629 edition. Another is that Brent was engaged in translating Sarpi's work in the late spring and early summer of 1619. People were also expecting that Parliament would be called later that year, even though it was not in fact summoned until November $1620 .{ }^{23}$ Moreover, the printing of the Italian edition of Sarpi's history (for which the dedicatory letter was dated January 1619 (i.e., 1620)) had been delayed by the need to

22 See Andrew Hegarty's life of Brent in $O D N B$; Lewis Atterbury, ed., Some Letters Relating to the History of the Council of Trent (London, 1705), 6-26; Paolo Sarpi, The Historie of the Councel of Trent (London, 1620), sig. \3r-4r, ๆ6r-v; Rees and Wakely, Publishing, Politics, and Culture, 108-109; Kew, TNA, SP 14/108, fol. 103r; SP 14/109, fol. 77r.

Atterbury, ed., Some Letters, $23^{-24}$ (the translation offered on pp. $25^{-26}$ is problematic); Kew, TNA, SP 14/108, fol. 103r-v; SP 14/109, fols 77r-v and 203. Abbot's copy of the 1620 edition of Brent's translation survives (Lambeth Palace Library, shelfmark *H83O 1545). 
revise the text, under Abbot's supervision, to remove unauthorised changes made by De Dominis. ${ }^{24}$ Also suggestive is the information, given in letters from Abbot to Brent at Venice in the summer of 1618 printed in the collection, that 'The Old Man, which was my Guest when you departed, doth tell me that there be some other things in the hands of our two good Friends [Sarpi and his biographer, Fulgenzio Micanzio], that are worth transcribing. ${ }^{25}$ Although this is most likely to be a reference to De Dominis himself, it might also indicate Savile. There is evidence both that Savile was already an admirer of Sarpi's writings and that friends referred to Savile affectionately as 'the Old Man' by $1618 .{ }^{26}$

These comments should indicate that Savile's engagement with the King's Printers to publish a book dealing with free will and predestination by order of Archbishop Abbot and with a dedication to James vi \& I was not a surprising act. Bradwardine's work spoke directly to issues raised in debate at Trent that Sarpi would address, notably in his treatment of the discussion of free will and predestination at the Council in $1546 .{ }^{27}$ At the same time, it echoed the debates in the Netherlands, in which James VI \& I had already intervened. These were watched closely by several members of Savile's circle. For example, Brent discussed the politics and doctrine of the Arminians with Abbot privately in November 1616. As Brent wrote to Carleton: 'He conde[m]neth Grotius for a busie bodie, for his ambition, for his indiscretion, and for a liar. He thinketh $\mathrm{y}^{\mathrm{t}}$ he slandereth his $\mathrm{Ma}[\mathrm{jesty}]$ : and $\mathrm{y}^{\mathrm{e}} \mathrm{B}$ [ishops] of England when he maketh them favourers of his partie, for if any do, it is only $y^{e}$ B. of Leechfeild. for $w^{\text {ch }}$ opinion his Grace alleaged many inducements. ${ }^{28}$ A worried Savile asked Carleton 'how scapes my acquay[n]ta[n]ce Grotius in this te[m]pest' as the controversy reached its political climax in February 1619. The debates at the Synod of Dort drew in further people that Savile knew directly. John Hales, whose career as a scholar of Greek Savile had sponsored at both Merton

24 Lambert B. Larking, 'Notes of Sir Roger Twysden on the History of the Council of Trent', Notes and Queries 2nd series 85 (1857), 121-124. Twysden's copy of the 1619 Italian edition of Sarpi's history is now at Washington, D. C., Folger Shakespeare Library, shelfmark STC 2176o copy 2.

25 Atterbury, ed., Some Letters, 7-8, 10-11 (quotation at 10).

26 Kew, TNA, SP 14/74, fol. 67r (Savile to Carleton, 14 July 1613); SP 14/92, fol. 143r (Richard Harrison to Dudley Carleton, 28 May 1617). For evidence that Abbot referred to De Dominis as 'the old man', see Anthony Milton, ed., The British Delegation at the Synod of Dort (16181619) (Woodbridge, 2005), 24, 26 (letters from Abbot to Carleton, 28 December 1617 and 8 January 1618).

27 Sarpi, Historie, 192-215.

28 Kew, TNA, SP 14/89, fols 72v-73r. The bishop of Lichfield was John Overall. 
and Eton, observed and reported on the Synod as Carleton's chaplain. Savile bemoaned the silence of Hales towards 'his poore frends at Eato[n]', which he attributed to the demands placed on him at Dordrecht. ${ }^{29}$ Samuel Ward (15721643), master of Sidney Sussex College, Cambridge, and, like Savile a member of one of the companies that had prepared the Authorised Version of the Bible (1611), was a delegate at the Synod. There he shared with Matthias Martinius, the delegate from Bremen who was close to members of the British delegation, ideas that derived directly from his reading of Bradwardine. ${ }^{30}$

The most important figure in the revival of the work of Archbishop Bradwardine, however, remained Archbishop Abbot. Abbot and his brother, Robert (1559/6o-1618), who was Regius Professor of Divinity at Oxford from 1612 until his elevation to the see of Salisbury in December 1615, were both consistent proponents of orthodox, predestinarian divinity. This was reflected not only in their own writings and their attitudes to the developing controversy over divine foreknowledge, grace and necessity and human free will in the contemporary Netherlands, but also in their efforts to control the form and content of preaching in the University of Oxford. Both men were involved in the controversy that came to a head in interviews conducted before the king with John Howson, canon of Christ Church, and William Laud, then president of St John's College, Oxford, in June 1615. Howson and Laud were both accused of handling disputed points in divinity in a manner that favoured Catholic authors in questions of doctrine and authority. ${ }^{31}$ Howson, in particular, had a long history of debate with Oxford Calvinists. In 1612, he had suggested that the annotations to the Geneva Bible concerning the doctrine of the Trinity supported Arianism. This incensed some of Savile's friends: Thomas Bodley wrote to Thomas James that 'I repute it a mater muche importing the honour \& credit of the Vniuersitie, and to say the very truth, the whole churche of this realme,

29 Kew, TNA, SP 14/105, fol. 194r.

30 See Milton, ed., British Delegation, liv. For the presence of Bradwardine in Ward's commonplace books, see Cambridge, Sidney Sussex College, Ms Ward I, fol. 8r-v; for Ward's praise of Savile, see Ms Ward I, fol. 53r. On later debate in the Netherlands over Bradwardine, see James Tanis, 'Abraham van der Heyden. A Seventeenth-Century Bradwardinian', in Augustine, the Harvest, and Theology (1300-1650), ed. Kenneth Hagen (Leiden, 1990), 333-348.

31 Nicholas Cranfield and Kenneth Fincham, eds, 'John Howson's Answers to Archbishop Abbot's Accusations at his "Trial” before James I at Greenwich, 10 June 1615, Camden Miscellany 29 (1987), 319-341; Kenneth Fincham, 'Prelacy and Politics: Archbishop Abbot's Defence of Protestant Orthodoxy', Bulletin of the Institute of Historical Research 61 (1988), 36-64; Michael Questier, Dynastic Politics and the British Reformations, 1558-1630 (Oxford, 2019), 361. 
that [Howson] should be censured seuerely.' 32 The echo of Bradwardine's own experience is not difficult to hear and it seems very likely that Abbot's sponsorship of a work against Pelagian divinity, which had originally been addressed directly to members of the University of Oxford, was far from coincidental. Savile's position in this debate is also clear from other evidence apart from his work on Bradwardine. In August 1618, he proposed to Carleton that John Prideaux, Robert Abbot's orthodox successor as regius professor in Oxford, should assist him by attending the Synod of Dort. ${ }^{33}$

Bradwardine had been specifically worried about the spiritual health of the Mertonians among whose number he continued to count himself. Savile presumably felt similar concern about the local sphere of controversy, which was however a manifestation of worrying developments within learned Christendom much more broadly. Debate in Oxford mirrored earlier developments in Cambridge (in particular the teaching of John Overall, by this time bishop of Lichfield). ${ }^{34}$ It echoed controversies that had developed over the teaching of Arminius at Leiden and more broadly in the Dutch Republic. Above all, it took place in the context of renewed discussion over the extent of divine foreknowledge and human freedom which divided Catholic theology (notably for members of the Jesuit order and at the University of Louvain, where it drew in English Catholic exiles), as well as sustaining debate between Catholics and Protestants. ${ }^{35}$ In response, the work of Bradwardine held out the promise of reconciling the truth of Christian doctrine, as it had been known in pre-Tridentine tradition, with orthodox Protestant teaching, without compromising such theology with contemporary errors sponsored by supposed Catholic semi-Pelagians and their presumed followers (notably Arminius and his allies) in the Reformed Churches. ${ }^{36}$

32 G. W. Wheeler, ed., Letters of Sir Thomas Bodley to Thomas James (Oxford, 1926), 227-228; see also Paul C. H. Lim, Mystery Unveiled. The Crisis of the Trinity in Early Modern England (New York, 2012), 277-280.

Kew, TNA, SP 14/98, fol. 117r. Archbishop Abbot later refused Carleton's suggestion that Prideaux be appointed on the basis that he 'cannot be provided so sudden': see Milton, ed., British Delegation, $157^{-158}$.

34 See H. C. Porter, Reformation and Reaction in Tudor Cambridge (Cambridge, 1958), 376-413; Anthony Milton, "Anglicanism by Stealth": The Career and Influence of John Overall', in Religious Politics in Post-Reformation England, eds Peter Lake and Kenneth Fincham (Woodbridge, 2006), 159-176.

For this debate, whose origins lay partly in the ideas of Luis de Molina, see Antonio Gerace, Biblical Scholarship in Louvain in the 'Golden' Sixteenth Century (Göttingen, 2019), 149-200.

36 This was certainly the eventual position of John Davenant, a delegate at Dort and Lady Margaret Professor of Divinity at Cambridge: see David S. Sytsma, 'Aquinas in Service of Dordt: John Davenant on Predestination, Grace, and Free Choice' in Beyond Dordt 
Bradwardine's writings provided Savile with a local means of scholarly intervention in theology by reference to someone with a broad doctrinal reach who had also shown particular respect for royal authority and who provided a model for the teaching of philosophy in the Platonic tradition from a grounding in Euclidean geometry. ${ }^{37}$ The parallel, in this respect, with Savile himself is clear. ${ }^{38}$ Savile drew it out in his preface to De causa Dei, where he dwelt on Bradwardine's achievements as a patron of astronomers, as a mathematician, and as a student of the science of motion. Savile believed that Bradwardine and his contemporaries wrote theology in a Euclidean style of hypothesis and demonstration..$^{39}$

Both Bradwardine's philosophy and his theology were in more general discussion in any event at Oxford in the early seventeenth century. Thomas James, Bodley's librarian, attributed to Bradwardine the belief of John Wyclif (whom he regarded as a proto-Protestant) 'in the nature of a true sole-iustifying faith, against merit-mongers and Pardoners, Pelagians, and Papists. ${ }^{40}$ Richard Field, the Oxford-educated prebend of Windsor who was being considered for succession to the bishopric of Oxford at his death in 1616, discussed a number of medieval Augustinians in his polemic in favour of the antiquity of Protestant belief and against Robert Bellarmine and the Tridentine doctrine of grace. Field claimed that Bradwardine advanced what was 'euer the doctrine of the Church of England' when he 'confirmeth and proueth' what Robert Grosseteste ( $c$. 1170-1253), Bishop of Lincoln, had argued. Field fleshed this out from Gregory of Rimini (1300-1358) in the following way: 'noe act morally good, canne bee done without the speciall grace of GOD, for if there bee noe vertue without such grace, then canne there bee noe act morallie good: which is yet more fully cleared: for euery vertuous and morall good act, either is orderly loue, or presupposeth it: soe that if there can bee noe orderly loue without GoDs grace, there can bee noe act of vertue, or act morally good. ${ }^{41}$ Bradwardine, for Field, held 'that God willeth those euils that are sinnes, \& that in respect of euery

and De Auxiliis. The Dynamics of Protestant and Catholic Soteriology in the Sixteenth and Seventeenth Centuries, eds Jordan J. Ballor, Matthew T. Gaetano, and David S. Sytsma (Leiden, 2019), 169-199.

37 Bradwardine, De cavsa Dei, ed. Savile, sig. a3v-4v, c4r-v, p. 876.

38 For Savile's recovery of the history of mathematics, see Robert Goulding, Defending Hypatia (Dordrecht, 2010).

39 Bradwardine, De cavsa Dei, ed. Savile, sig. a2v, azv.

40 Thomas James, An Apologie for Iohn Wickliffe (Oxford, 1608), sig. k3v.

41 Richard Field, Of the Church, Five Bookes, 2nd edn, ed. Nathaniel Field (Oxford, 1628), 261; for Field's life, see the entry by Vernon G. Wilkins in $O D N B$. These passages of the third book were added to the text of the first edition of 1606, based on notes left incomplete by Field at his death. 
thing, he hath an act of will, either that it shalbe, or not be, and not a meere negation of such act.'42

For Field, Bradwardine was notable for the way in which he provided a method of engagement with the theology and philosophy of contemporary Catholic scholasticism. ${ }^{43}$ His ideas on free will, grace, and necessity, could be assimilated to those of other orthodox medieval doctors, notably Grosseteste. This was a position that was shared by Thomas James. ${ }^{44}$ Savile too may have been sympathetic to it. Certainly, he was at work on a Merton manuscript of Grosseteste with a view to publishing his letters at much the same time as his edition of Bradwardine was going through the press. ${ }^{45}$ For all of these writers, the example of Bradwardine provided evidence that the medieval Church had properly embraced positions closer to those of Protestantism than to those enunciated at the Council of Trent and defended by contemporary Catholicism. ${ }^{46}$

Savile's interest in Bradwardine, however, seems to have begun much earlier than 1617. Indeed, it can be dated fairly exactly to the time that work on the Eton edition of Chrysostom was coming to an end and that Howson's preaching was causing a furore in Oxford. Evidence for this derives from two sources. The first of these is Samuel Clarke's posthumous life of William Twisse (1577/8-1646). Twisse was an undergraduate at New College, Oxford, where he was later a fellow. At some point, he may have been a pupil of Robert Abbot and he became a prominent controversialist, in particular opposing the ideas of the Oxford Platonist, Thomas Jackson. In this context, he returned consistently to Bradwardine's teaching. He cited Bradwardine on divine perfection, on the limitlessness of God's power ('who can doe all thinges that imply not contradiction'), the necessity of divine being, and the

42 Field, Of the Church, 128.

43 For the relevance of Bradwardine's ideas of space and extension to scholastic philosophy, including that of the Jesuit, Francisco Suárez, and the Coimbra commentators, see Edward Grant, Much Ado about Nothing (Cambridge, 1981), 153-174. For Bradwardine's relevance to Catholic debates over free will and necessity, as they played out in contemporary Protestant theology, see Ballor, Gaetano, Sytsma, eds, Beyond Dordt and De Auxiliis; J. Martin Bac, Perfect Will Theology. Divine Agency in Reformed Scholasticism as against Suárez, Episcopius, Descartes, and Spinoza (Leiden, 2010).

44 James, Apologie, sig. k3v: 'that true great Clearke Rob. Grosthead'.

45 See a letter of Thomas Gataker to James Ussher, 24 June 1617, printed by Elizabethanne Boran, ed., The Correspondence of James Ussher, 3 vols (Dublin, 2015), 1: 129.

46 On the debate over the visibility of doctrines associated with Protestantism in medieval Christianity, see Anthony Milton, 'The Church of England, Rome, and the True Church: The Demise of a Jacobean Consensus', in The Early Stuart Church, 1603-1642, ed. Kenneth Fincham (Basingstoke, 1993), 187-210, 282-285. 
degrees of divine rewards and punishments according to human merit. ${ }^{47}$ According to Clarke, Twisse 'took his Degree of Doctor, with a general applause. For he had before given a great manifestation... of his Learning... in transcribing, and judiciously correcting the Writings of that profound Doctor, Thomas de Bradwardine, which were to be Published by Sir Henry Savil.'48 As Luca Baschera points out, if Clarke is to be believed, Twisse's work on Bradwardine must have occurred before 5 July 1614, when he became a doctor of divinity. ${ }^{49}$ A second piece of evidence is more revealing. On 26 January 1612 (i.e., 1613), Samuel Ward wrote to Thomas James, asking him 'as soone and as safely as you can to send my Manuscript Bradwardin to Abraham Segard, Stationer within Blackfriars. He will see it safelie conveyed vnto me to Cambridge. 50

Ward's letter to James is interesting in a number of ways. As has already been noted, both James and Ward were themselves readers of Bradwardine. As early as 160o, James had drawn attention to the presence of manuscripts in English libraries of De causa Dei, which he considered one of the most important unpublished works of old religious controversy, favourable to Protestantism. ${ }^{51}$ Moreover, the bookseller Abraham Segard, who was probably a Huguenot exile, later acted as an agent for John Bill. ${ }^{2}$ The manuscript mentioned in the letter is almost certainly the fourteenth-century copy of $D e$ causa Dei bequeathed by Ward to Sidney Sussex College, Cambridge, in $1643 .{ }^{53}$

47 William Twisse, A Discovery of D. Iacksons Vanitie ([Amsterdam], 1631), 15-16, 94-97, 356-7, 456, 686. See also William Twisse, The Doctrine of the Synod of Dort and Arles ([Amsterdam, 1631]), 68; William Twisse, Opera (Amsterdam, 1652); Cambridge, Sidney Sussex College, uncatalogued correspondence of John Davenant, William Twisse, and Samuel Ward (1630-1632). The interpretation of this debate given by Sarah Hutton, 'Thomas Jackson, Oxford Platonist, and William Twisse, Aristotelian', Journal of the History of Ideas 39 (1978), $635^{-6} 5_{2}$, needs to be modified to take account of Twisse's broader interest in the divinity of Scotus and Aquinas, which helped to define his interpretation of human free will (see Richard Muller, Divine Will and Human Choice: Freedom, Contingency, and Necessity in Early Modern Reformed Thought (Grand Rapids, 2017), 225-235).

48 Samuel Clarke, The Lives of Sundry Eminent Persons in this Later Age (London, 1683), 14.

49 Baschera, 'Witnessing to the Calvinism of the English Church', 441.

$50 \quad$ G. W. Wheeler, ed., Letters Addressed to Thomas James (Oxford, 1933), 64, printing Oxford, Bodleian Library, Ms Ballard 44, fol. 153 .

$5^{1} \quad$ Thomas James, Ecloga Oxonio-Cantabrigiensis (London, 16oo), 143.

$5^{2}$ See William John Charles Moens, ed., The Registers of the French Church, Threadneedle Street, London: Volume I (Lymington, 1896), 88; Ian Michael, 'John Bill, agente librero de sir Thomas Bodley, impresor real de Jacobo I y librero Londinense del primer conde de Gondomar (I)', Avisos. Noticias de la Real Biblioteca 12 (2006), 6-8.

53 Cambridge, Sidney Sussex College, Ms 9o; Montague Rhodes James, A Descriptive Catalogue of the Manuscripts in the Library of Sidney Sussex College, Cambridge (Cambridge, 1895), 
Like Field and Savile, Ward also associated Bradwardine's theology with that of Grosseteste. ${ }^{54}$ The transmission of Ward's manuscript to Oxford indicates that James was already involved in preparation of a copy of the text (of which the Bodleian had no version), but the rest of the letter suggests that this plan had been abandoned. Ward wrote: 'Sorry I am that you doe not proceed to the setting forth of it, I dowbt not but $\mathrm{M}^{\mathrm{r}}$ Rimey would give you in Copies of the book so many as would make vp that which he is behind with you. ${ }^{55}$ Presumably, therefore, Twisse took up the work that James had begun. It seems likely that it was carried on under Savile's direct supervision from the summer of 1615 (and just after Abbot's interview with Howson) until the autumn of 1616, since Savile told Carleton on 3 September 1616 that he was returning to Eton having spent almost fourteen months in Oxford. ${ }^{56}$

When Savile worked on the edition of Chrysostom, he built up an extensive network of international contacts, whose members provided him with copies of Greek manuscripts from places as far away as Mount Athos. He borrowed manuscripts from libraries in Oxford and benefitted from the professional work of Greek scribes at the Vatican Library. ${ }^{57}$ After the book was published, Savile was careful to reward those who had helped him, in order that they might provide him with further copies of manuscripts in the future. ${ }^{58}$ Eventually, in 1620 , he deposited the working papers of the edition, including both manuscripts and adversaria recorded on the pages of earlier printed versions, in the Bodleian

73; Nicholas Rogers, ‘The Early History of Sidney Sussex College Library', in Sidney Sussex College Cambridge. Historical Essays, eds D. E. D. Beales and H. B. Nisbet (Woodbridge, 1996), $75^{-88 .}$

54 Cambridge, Sidney Sussex College, Ms Ward I, fol. 8v; see also ms 92, a copy of a Durham manuscript of Grosseteste's letters.

55 Wheeler, ed., Letters Addressed to Thomas James, 64. ' $\mathrm{M}^{\mathrm{r}}$ Rimey' may be the bookseller James Rime or Ryme or Rymer (stepson of Ascanius de Renailme), see McKerrow, ed., Dictionary of Printers and Booksellers, 228. See also [Thomas James], The First Printed Catalogue of the Bodleian Library 1605 (Oxford, 1986). No copy of De causa Dei is listed among the manuscripts of Bradwardine held at the Bodleian in [Edward Bernard, ed.], Catalogi librorum manuscriptorum Anglice et Hibernice (Oxford, 1697); see also R. W. Hunt, ed., A Summary Catalogue of the Western Manuscripts in the Bodleian Library. Volume I (Oxford, 1953), 76-122.

$5^{6}$ Kew, TNA, SP 14/88, fol. 116r.

57 For an outline, see S. L. Greenslade, 'The Printer's Copy for the Eton Chrysostom, 161013', Studia Patristica 7 (1966), 6o-64; Jean-Louis Quantin, 'Du Chrysostome latin au Chyrsostome grec. Une histoire européenne (1588-1613)', in Chrysostomosbilder in 1600 Jahren, eds Martin Wallraff and Rudolf Brändle (Berlin, 2008), 267-346; N. G. Wilson, $A$ Descriptive Catalogue of the Greek Manuscripts of Corpus Christi College, Oxford (Cambridge, 2011), 33 .

$5^{8}$ See, for example, Kew, TNA, SP 14/77 fol. 53r-v (Savile to Carleton, 1 June 1614). 
Library. ${ }^{59}$ Savile's behaviour in editing Bradwardine was different, although he seems to have drawn on at least one source located overseas. For the most part, however, the edition rested on manuscripts found closer to home. In the preface, Savile made three claims about his sources. ${ }^{60}$ The first of these was contextual: the book had been arranged by Bradwardine largely from his Oxford lectures and had been completed as part of an appeal to his fellow Mertonians, when he was chancellor of St Paul's. The second claim was that Savile had edited the text from six manuscripts. The third was that the 'epigraph' in each of these manuscripts was the same as the one that Savile himself printed ('Explicit istud opus, De causa Dei contra Pelagium, \& de virtute causarum, \& virtute Dei causce causarum; perscriptum London, anno millessimo trecentisimo quadragesimo quarto Dom. Iesu Christi'), except in two cases. ${ }^{61}$ The two exceptions were the copy found at New College, Oxford, whose title was 'Summa Doctoris profundi de causa Dei contra Pelagianos, \& de virtute causarum, virtute Dei causce causarum', and that in the Vatican Library: 'Summa Doctoris Profundi Thomce Bradwardini de causa Dei contra Pelagianos, \& de virtute Dei causce causarum.' ${ }^{2}$

These comments would seem to make it straightforward to identify how Savile went about preparing the text of De causa Dei. It is not strictly correct to claim with Luca Baschera that Savile 'mentions that the printed text relies on six manuscripts, but specifies the provenience [sic] only of two of them.'.63 Nevertheless, the difficulty that Oberman and others have had in identifying precisely which manuscripts Savile used is not without explanation. ${ }^{64}$

There can be no doubt that the New College manuscript that Savile described is the copy of De causa Dei that can now be found in that College's library as MS 134. Thomas James, then a fellow of New College, opened the union catalogue of the manuscripts to be found in Oxford and Cambridge libraries that he published in 1600 with a list of the manuscripts of his own College. This manuscript is number 22 in that list and is the only copy of $D e$ causa Dei to be found there. ${ }^{65}$ It had been given to New College by William

59 Oxford, Bodleian Library, Mss Auct. E. 3. 1.-4. 6.

6o Bradwardine, De cavsa Dei, ed. Savile, sig. azr.

61 The epigraph (or, as one would now say, explicit) is found at Bradwardine, De cavsa Dei, ed. Savile, 876 .

62 Bradwardine, De cavsa Dei, sig. azr.

63 Baschera, 'Witnessing to the Calvinism of the English Church', 440.

64 Oberman, Archbishop Thomas Bradwardine, 18-20.

65 Thomas James, Ecloga, p. 2. See also H. O. Coxe, Catalogus codicum mss. qui in Collegiis Aulisque Oxoniensibus hodie adservantur, 2 parts (Oxford, 1852), 1/7: 49; William Poole and Christopher Skelton-Foord, eds, Geometry and Astronomy in New College, Oxford (Oxford, 2019), 67 . 
Rede (c.1315-1385), a mathematician and astronomer who was consecrated as bishop of Chichester by the Pope in Avignon in 1369. Rede had become a fellow of Merton no later than 1344 and at his death had a library of some 370 books. He was a remarkable donor of one hundred books to that college and also of one hundred books to New College, as well as a lesser donor to the libraries of Exeter, Queen's, Balliol, and Oriel colleges. ${ }^{66}$ His copy of De causa Dei was one of several books that he bought with money given to him by his patron, Nicholas of Sandwich. ${ }^{67}$ Rede's manuscript was on hand for both James and later Twisse to use, assuming that one or both of them acted as amanuenses in the preparation of Savile's edition at one time or another. Its ownership and associations were redolent of the Merton of Bradwardine which so attracted Savile. It was also bound with the questiones on predestination of Thomas of Buckingham, a contemporary of Bradwardine in Merton's fellowship.

The only difficulty concerning this manuscript is that its explicit reads: 'Explicit istud opus de causa dei contra pelagium, et de virtute causarum, v[ir] tute dei cause causarum, $\mathrm{p}$ [er]scriptum London[iis], anno millesimo trecentesimo q[ua]dragesi[m]o quarto $\mathrm{d}[\mathrm{o}] \mathrm{m}[\mathrm{ini}]$ ihesu cristi. ${ }^{68}$ Allowing for slight variations in spelling and in the expansion of abbreviations, this is exactly the colophon that Savile printed. Yet, in the preface to De causa Dei, he told the reader that the New College manuscript had a different epigraph. Some of the text that he gave there as part of the title of the New College manuscript is to be found on the flyleaf that records Rede's purchase and subsequent donation of the book. There one may read: 'S[um]m[a] doctoris $\mathrm{p}[\mathrm{ro}]$ fundi de causa dei cont[ra] Pelagiu[m] [e]t de virtute cau[sarum]. 3. Libros continens.' Finally, the opening of the book has the rubric: 'de causae dei [con]tra pelagiu[m], et de $v$ [ir]tute causa[rum]... ${ }^{69}$ Nevertheless, even a combination of these three titles, written at different times in different hands, does not produce exactly the text that Savile claimed the New College manuscript bore. The correct conclusion to draw from this is not that Savile did not use the New College manuscript as one of his copy texts, indeed as one of the most significant of them. Instead, it is that one must use the clues Savile gave us with care.

66 A. B. Emden, A Biographical Register of the University of Oxford to A.D. 1500, 3 vols (Oxford, 1957), 3: 1556-1560; F. M. Powicke, The Medieval Books of Merton College (Oxford, 1931), 2832, 87-92.

67 Oxford, New College, MS 134, verso of flyleaf.

68 Oxford, New College, Ms 134, fol. 322 r.

69 Oxford, New College, Ms 134, fol. 1r. Savile pointed out that the title 'Doctor profundus' had been bestowed on Bradwardine by the Pope: Bradwardine, De cavsa Dei, ed. Savile, sig. azv. He suggested that this implied that the Mertonian had the same standing as Scotus and Aquinas. 
Before turning to the Vatican manuscript that Savile also named, it is worth trying to track down the other four sources that he used. Savile reproduced a colophon dated 1344 as part of his standard epigraph for the text. He clearly thought that this was significant and that it indicated a copy made at or very close to the time when Bradwardine completed his book. A copy of De causa Dei, bequeathed by Bradwardine's contemporary, John Staveley, had been recorded in a mid-fourteenth-century list of the theological books owned by Merton College. ${ }^{70}$ This volume was lost, however, by the time of Savile. Merton nevertheless owned another fourteenth-century copy of De causa Dei which was fundamental to Savile's edition (and whose general appearance was remarkably similar to the manuscript at New College). Its epigraph read: 'Explicit istud opus de c[aus]a d[e]i c[ontra] pelagiu[m] \& de virtute causar[um] virtute $\mathrm{d}[\mathrm{e}] \mathrm{i}$ cause causar[um] p[er]scriptu[m] London[iis] anno milesimo trecentesimo quadragesimo quarto $\mathrm{d}[\mathrm{o}] \mathrm{m}[\mathrm{ini}] \mathrm{Ih}[\mathrm{e}] \mathrm{su} \mathrm{Chr}[\mathrm{ist}] \mathrm{i} .{ }^{71}$ Two features of this book were particularly striking to Savile, since they were incorporated into his edition but did not feature elsewhere in the manuscript tradition of De causa Dei. One of these was the opening letter of Bradwardine, introducing the book to his Mertonians, which Savile printed between Bradwardine's preface and the opening of book 1 of De causa Dei. This was found added at that location in the otherwise blank second column of folio $4 \mathrm{v}$ in the manuscript. The other was also added in the same hand, this time after the explicit of the work, again where Savile chose to print it. It was a letter from Bradwardine to his Mertonians accompanying the completion of his text. These two letters were critical for Savile's location of Bradwardine's book as a pastoral as well as a doctrinal text, addressed to contemporary Oxford readers. Both letters were in fact copied in the hand of Simon Lambourne, fellow of Merton from 1347 to 1361, who also recorded on the flyleaf of the manuscript that he paid seven marks for having the text of the book written out (probably in Oxford) in $1369 .{ }^{72}$ Lambourne had died by 1387 . His manuscript was given to Merton and appears in a list of books that can be dated to before $13855^{73} \mathrm{~A}$ seventeenth-century hand recorded on the flyleaf of the manuscript that it was a gift from Lambourne. Savile, however, paid no attention either to the donor or to the real date of writing of the manuscript in his edition. Other features of the Merton manuscript also

\footnotetext{
$70 \quad$ Powicke, Medieval Books of Merton College, 23, 120.

71 Oxford, Merton College, Ms 71, fol. 266v.

72 Oxford, Merton College, MS 71, fols 4v, 266v, iv. On Lambourne, see Emden, Biographical Register, 2: 1087. See also R. M. Thomson, A Descriptive Catalogue of the Medieval Manuscripts of Merton College, Oxford (Cambridge, 2009), 73-74. 
betray its importance for the editing of Savile's text. For example, the layout of the table on page 13 of Savile's edition is closer to that found in the Merton manuscript than the more elaborate form of presentation in the New College manuscript. ${ }^{74}$ In the main body of the text itself, Savile normally followed the Merton manuscript, printing its text while recording variants from the New College manuscript (and others) in the margin. This included printing some but not all of the apparatus of biblical and other textual references given in the margins of the New College manuscript, but found less extensively in the Merton manuscript.

Thomas James had recorded the existence of a manuscript of De causa Dei at Merton in $1600 .{ }^{75}$ As noted above, he knew of Samuel Ward's copy of the book before 1613 . This manuscript, which is more elaborately decorated than either the copy at Merton or that at New College, also bears the epigraph that Savile identified as being found in copies that he used for his edition. Here, indeed, it takes almost exactly the form that Savile printed: 'Explicit istud opus de causa dei cont [ra] pelagiu[m] et de virtute causarum, virtute dei cause causarum. Perscriptum London[iis]. Anno millesimo trecentesimo quadragesimo quarto domini nostri Jhesu Cristi. ${ }^{76}$ Textually, Ward's manuscript was closer to that at New College than it was to the one at Merton. In addition to the manuscripts at New College and Merton, James knew of four other copies of De causa Dei in 16oo. These were located at Oriel College, Oxford; Corpus Christi College, Cambridge; Peterhouse, Cambridge; and in the private library of Lord Lumley. ${ }^{77}$

Details of the manuscript at Oriel are hard to obtain. It was volume 55 in James's list of 71 manuscripts at the college in 1600 . By no later than 1697 , it was no longer there. ${ }^{78}$ It is possible that it was one of the manuscripts used by Savile. It is more likely, however, that Savile made use of MS 24 in the library of Corpus Christi College, Cambridge. ${ }^{79}$ This had entered the collections of Matthew Parker (1504-1575), archbishop of Canterbury, on 20 December 1567, possibly as a gift from Andrew Perne, master of Peterhouse. Bequeathed by Parker to his Cambridge College, this manuscript originally came from the Benedictine cathedral priory at Worcester, to which it had been given by the monk, John de Preston, in 1348. It is textually similar to New College MS 134, but in terms of

\footnotetext{
74 Oxford, Merton College, MS 71, fol. 8r; Oxford, New College, MS 134, fol. 1or.

75 James, Ecloga, 16.

76 Cambridge, Sidney Sussex College, Ms 9o, fol. $\mathrm{u}^{4} \mathrm{r}$.

77 James, Ecloga, book two, 22.

78 James, Ecloga, 45; [Bernard, ed.], Catalogi, part two, 27-28, listing 72 manuscripts.

79 See James, Ecloga, 81, also noticing contemporary biographical information about Bradwardine found on the flyleaf of the manuscript. Cf. Bradwardine, De cavsa Dei, ed. Savile, sig. a4v.
} 
layout and decoration is more reminiscent of Merton MS 71. Its epigraph reads: 'Explicat istud opus de causa dei c[ontra] pelagiu[m] \& de virtute causar[um] virtute dei cause causar[um] p[er]scriptu[m] London[iis] anno milesimo trecentesimo quadragesimo q[ua]rto $\mathrm{d}[\mathrm{o}] \mathrm{m}[\mathrm{ini}] \mathrm{Jh}[\mathrm{es}] \mathrm{u}$ [Christ]i.' It is in fact probably the oldest datable manuscript of De causa Dei that was available to Savile and was a fourth copy of the text whose epigraph might have led him to believe that it was written (or copied) in $1344 .{ }^{80}$ It seems plausible that, like New College MS 134 and Merton MS 71, it was written in Oxford, where de Preston had been a scholar. ${ }^{81}$ Corpus Christi MS 24 was also the source of one of the earliest discussions in print in England of Bradwardine's ideas of the dependence of free will on divine grace and divine necessity. The Cambridge divine William Perkins (1558-1602) cited Bradwardine, to demonstrate the historical context for what were now Protestant ideas, in his work about the false claims to catholicity of the Roman Church. The book was published posthumously by Perkins's former pupil, Samuel Ward. ${ }^{82}$

In 16oo, Thomas James had identified two more manuscripts of De causa Dei. One of these was in the library at Peterhouse, Cambridge, where it had been catalogued in 1418 and was seen by John Bale about 130 years later. Another was in the private library of John, 1st Baron Lumley at Nonsuch. ${ }^{83}$ By the time that Savile was at work on his edition, both of these manuscripts had entered the library of Richard Bancroft, archbishop of Canterbury, and were therefore now under the care of his successor, George Abbot. ${ }^{84}$ The first, which has cautions entered by fifteenth-century Cambridge masters, including one

8o Cambridge, Corpus Christi College, Ms 24, fols iiiv and 271v. See also Montague Rhodes James, A Descriptive Catalogue of the Manuscripts in the Library of Corpus Christi College Cambridge, 7 parts (Cambridge, 1909-1913), 1: 47 .

81 Emden, Biographical Register, 3: 1518; R. M. Thomson, A Descriptive Catalogue of the Medieval Manuscripts in Worcester Cathedral Library (Cambridge, 2001), xxvi-xxvii.

82 William Perkins, Problema de Romance fidei ementito Catholicismo, ed. Samuel Ward (Cambridge, 1604), 72. Savile referred directly to Perkins's use of Bradwardine, along with that of the Catholic jurist and editor of the Tridentine canons and decrees, Orazio Luzi: Bradwardine, De cavsa Dei, ed. Savile, sig. azr. See also W. B. Patterson, William Perkins and the Making of a Protestant England (Oxford, 2014), 197-198.

83 James, Ecloga, part two, 22; Peter D. Clarke, ed., The University and College Libraries of Cambridge, Corpus of British Medieval Library Catalogues 10 (London, 2002), 472; John Bale, Index Britanniae scriptorum, ed. Reginald Lane Poole, with an introduction by Caroline Brett and James Carley (Woodbridge, 1990), 432; Sears Jayne and Francis R. Johnson, eds, The Lumley Library. The Catalogue of 1609 (London, 1956).

84 They are now Lambeth Palace Library, Mss 32 and 169 respectively. See R. M. Thomson, $A$ Descriptive Catalogue of the Medieval Manuscripts in the Library of Peterhouse, Cambridge (Cambridge, 2016), 205; Montague Rhodes James, A Descriptive Catalogue of the Manuscripts in the Library of Lambeth Palace: The Medieval Manuscripts (Cambridge, 1932), 
by William Dyngley (who can be associated with several books at Peterhouse), is written in several hands and has some of the textual features of New College MS 134. Its epigraph reads: 'Explicit istud opus de ca[usa] d[e]i [con] tra pelagiu[m] \& de v[ir]tute cau[sa]r[um] d[e]i Thome de Bradwardyna Cancellarii London[ii] p[er]scriptu[m] Cantebriggie Anno d[o]m[ini] millesimo CCC $^{\circ}$ octogesimo quinto Editum ab eode[m] Thoma London[ii] anno d[o]m[ini] mill[es]i[m]o ccc q[ua]dragesimo q[ua]rto.'85 Despite the fact that it was copied at Cambridge in 1385, this manuscript therefore also bears a colophon that suggests that De causa Dei was written in 1344. Although the wording of the explicit differs very slightly from that favoured by Savile, it seems most unlikely that he would not have made use of a manuscript of De causa Dei in the possession of the archbishop who ordered that the book be published. This manuscript, moreover, was the last complete or near complete copy of the text known to Thomas James. The book that had belonged to Lord Lumley has features of the appearance, layout, and textual variants of New College MS 134, but it is incomplete and breaks off at the end of book 1 of De causa Dei. ${ }^{86}$

There were other manuscripts of De Causa Dei that were recorded in seventeenth-century England, for example a second copy from the cathedral priory at Worcester (where it was catalogued by the royal librarian, Patrick Young, in 1622-1623), or a copy in the library of Lincoln Cathedral. ${ }^{87}$ They seem less likely, however, as copy texts for Savile's edition than any of the books already discussed. This is also true of manuscripts overseas that bore a colophon with the date $1344 .{ }^{88}$ Information from a sixth manuscript was, however,

46-47, 265-266; James Carley, ed., “Accurately and exquisitely made": George Abbot's Preface to the 1612 Catalogue of Lambeth Palace Library', in From the Reformation to the Permissive Society, eds Melanie Barber, Stephen Taylor and Gabriel Sewell (Woodbridge, 2010), 43-62; Jayne and Johnson, eds, The Lumley Library, 302. I am grateful to James Carley for advice about the entry for 'de Bradwardina de causa Dei contra Palagium. fo . bis' in the post-mortem list of Bancroft's library (Lambeth Palace Library, MS LF/F/1). Both books were among those moved to Cambridge University Library in 1647 and rearranged on their return to Lambeth by Archbishop Sancroft: see N. R. Ker, 'Archbishop Sancroft's Rearrangement of the Manuscripts of Lambeth Palace', in A Catalogue of Manuscripts in Lambeth Palace Library, Mss. 1222-186o, ed. E. G. W. Bill (Oxford, 1972), 1-53, at 5-6, 29.

85 Lambeth Palace Library, Ms 32, fol. 257r.

86 Lambeth Palace Library, Ms 169.

87 Thomson, Worcester Cathedral Library, 75; Patrick Young, Catalogus librorum manuscriptorum bibliothecae Wigorniensis Made in 1622-1623, eds Ivor Atkins and Neil R. Ker (Cambridge, 1944), 51; R. M. Thomson, Catalogue of the Manuscripts of Lincoln Cathedral Chapter Library (Cambridge, 1989), 11 (incomplete).

88 For example, Padua, Basilica di Sant' Antonio, MS 170, whose colophon matches that identified by Savile. See Luigi M. D. Minciotti, Catalogo dei codici manoscritti esistenti nella biblioteca di Sant'Antonio di Padova (Padua, 1842), 59. 
used. This came from the Vatican Library. According to Oberman and others, Ms Vat. Lat. 1038, a manuscript whose colophon is dated 1357 and which was copied at Paris by Gerit Baptiste of Diest, is the most likely candidate to have been consulted by Savile or his agents. This book was in the collections of Gregory XII in $1411{ }^{89}$ Unfortunately, the explicit of this manuscript does not match Savile's own description of his source at the Vatican and, moreover, the text contains significant variants which are not recorded by Savile. By contrast, the richly illustrated manuscript written at Rome in 1411 by the Augustinian Boezio da Tolentino, matches both Savile's description of its epigraph and contains readings which, like those of New College MS 134, can be found in the margin of Savile's text. It entered the library of Nicholas V from the collections of the Carmelites. Its explicit reads: 'Explicit Sum[m]a doctoris $\mathrm{p}[\mathrm{ro}]$ fundi thome brauardini de causis dei [con]t[ra] pelagian[orum] et de virtute dei cause causarum. ${ }^{90}$ It was presumably particularly important to Savile to obtain a Roman example of a manuscript acknowledging Bradwardine's status as 'Doctor profundus', the title that he had been given by the Pope in Avignon.

Savile therefore brought to fruition a project that Thomas James and Samuel Ward had canvassed and carried it out with the help of James, Ward, and Twisse. Others who perhaps aided him by making copies of materials may have included John Wilton, chaplain of Merton. In 1619, Wilton wrote to the bookseller, Thomas Thorpe, about copies of the manuscript biblical commentaries of the Dominican Nicholas de Gorran that he was sending to Savile. ${ }^{91}$ When Savile's edition of De causa Dei appeared, it was immediately swept up by the debates about Arminianism then convulsing both the English and the Dutch churches. Its occasion, however, seems to have been a much more local dispute about the preaching of Reformed divinity in Oxford. In both contexts, Archbishop Abbot played a major role, even as his political power began to wane after 1618. The project of editing De causa Dei was conducted under Abbot's patronage and depended in part on books from the Archbishop's library.

The publication of De causa Dei represented in many ways the beginning rather than the end of Bradwardine's influence on the debate over free will and

89 Oberman, Archbishop Thomas Bradwardine, 18; Auguste Pelzer, Codices Vaticani Latini. Tomus II, pars prior (Vatican City, 1931), 546-547; Antonio Manfredi, I Codici latini di Niccolò V, Studi e Testi 359 (Vatican City, 1994), 278-279.

90 Vatican City, Biblioteca Apostolica Vaticana, MS Vat. Lat. 1040, fol. $305 \mathrm{v}$.

91 Cambridge University Library, Ms Add. 4251/150o. Tentatively dated to 8 February 1619 from its discussion of Thomas Cartwright, A Confvtation of the Rhemists Translation ([Leiden], 1618). On Thorpe, see McKerrow, ed., Dictionary of Printers and Booksellers, 265-266. I am grateful to Thomas Roebuck for sharing his thoughts about this letter. 
predestination in the English-and Dutch-speaking churches of the seventeenth century. ${ }^{92}$ Twisse and Ward, in particular, of those who had been involved in the edition continued to refer to Bradwardine extensively in their own writings of the 1620 s and 1630 s. Increasingly, however, the position that they represented lost out in a new generation of avant-garde readers, more critical of the positions of Perkins or, indeed, Savile. It is fitting to end a discussion of the way in which public teaching about predestination, whether in Oxford or in Leiden, had created an atmosphere for the revival of fourteenth-century divinity with another controversy about preaching. In January 1625, Samuel Ward preached a sermon in the university church (Great St Mary's) at Cambridge about grace. There, he cited 'our Bradwardine, the most strenuous proponent of the grace of God' ('Bradwardinus noster, gratiæ Dei strenuissimus assertor'), from Savile's edition, in the context of an Augustinian attack on the supposed Pelagianism and semi-Pelagianism of the Jesuits and the Remonstrants. ${ }^{93}$ For one of his readers, Matthew Wren (1585-1667), newly appointed master of Peterhouse and future bishop of Hereford, Norwich, and eventually Ely, this was all too much. Bradwardine was 'an enemy of God' ('hostis dei'), who lived his life in a manner contrary to faith. In place of Bradwardine, Wren cited the opinion of the heterodox reformer, Francesco Stancaro, which had won praise from Bellarmine: the teaching of Peter Lombard (on which Ockham had commented) was worth more than that of a hundred Luthers, two hundred Melanchthons, three hundred Bullingers, four hundred Peter Martyrs, or five hundred Calvins. ${ }^{94}$

92 See Tanis, 'Abraham van der Heyden'; Baschera, 'Witnessing to the Calvinism of the English Church', 441-446; Aza Goudriaan, 'Samuel Rutherford on the Divine Origin of Possibility', in Reformed Orthodoxy in Scotland, ed. Aaron Clay Denlinger (London, 2015), 141-156; Simon J. G. Burton, 'Disputing Providence in Seventeenth-Century Scottish Universities: The Conflict between Samuel Rutherford and the Aberdeen Doctors and its Repercussions', History of Universities 29 (2016), 121-142.

93 Samuel Ward, Gratia discriminans (London, 1626), 22-23, 42.

94 Wren's comments may be found in an interleaved copy of Ward's sermon: Oxford, Bodleian Library, shelfmark $4^{\circ}$ Rawl. 15o, especially at p. 37 (and facing), facing page 43, and facing page 54. See also Anthony Milton, Catholic and Reformed (Cambridge, 1995), 314; Stephen Hampton, 'Samuel Ward and the Defense of Dordt in England', in Beyond Dordt and De Auxiliis, eds Ballor, Gaetano, and Sytsma, 200-218. For Wren's public quarrel with Ward over teaching in the University in 1627-1628, see Margo Todd, 'Anti-Calvinists and the Republican Threat in Early Stuart Cambridge', in Puritanism and its Discontents, ed. Laura Lunger Knoppers (Newark, 2003), 85-105. 